\begin{tabular}{ccr} 
FOLIA & ENTOMOLOGICA & HUNGARICA \\
& ROVARTANI KÖZLEMÉNYEK & \\
Volume 81 & 2020 & pp. 129-142 \\
\hline
\end{tabular}

\title{
The tropical butterflies and skippers of Tobias Koy's collection (Lepidoptera: Papilionoidea and Hesperioidea)
}

\author{
Zsolt BÁLInT*, Gergely Katona \& Balázs TóTH \\ Hungarian Natural History Museum, Department of Zoology, H-1088 Budapest, Baross utca 13, \\ Hungary.E-mails: balint.zsolt@nhmus.hu,katona.gergely@nhmus.hu,toth.balazs@nhmus.hu
}

\begin{abstract}
The collection of Tobias Koy (1757-1829) includes the oldest Lepidoptera specimens preserved in the Hungarian Natural History Museum, originating from the turn of 18th and 19th centuries. These are kept in individual glassine trays. Several trays contain a specimen of exotic (non-European) species, as well as of species discovered in Europe after the death of Koy. We assume that trays containing specimens with these two kinds of origin were arranged by Imre Frivaldszky, so as to display the most valuable peculiarities of Koy's collection. Twelve exotic specimens are listed and characterised. The 150th anniversary of the death of Imre Frivaldszky gives the special actuality of this paper. With 17 figures.
\end{abstract}

Key words - anniversary, exotic species, glassine tray, Hungarian Natural History Museum, Imre Frivaldszky.

\section{INTRODUCTION}

Imre (= Emerich) Frivaldszky, who was born in 1799, died 150 years ago, in 1870 . Beside his remarkable contribution to botany, as member of the academic society "Magyar Tudós Társaság" he was the doyen of zoology in Hungary, especially in entomology. His collections were purchased by the Nemzeti Múzeum (National Museum of Hungary). Nowadays the Frivaldszky specimens belong to the most precious ones of the Hungarian Natural History Museum (HNHM), as they are vouchers of novel faunistic records and name bearing types, many of them are still waiting for recognition (Bálint, in prep.).

In his early career, Frivaldszky purchased the entomological library and Lepidoptera collection of Tobias Koy (1757-1829), who was one of the pioneers in the exploration of the Lepidoptera fauna of the Carpathian Basin (BÁLINT 2002). The collection of Koy was curated in a manner of "curiosity" when every specimen was kept in individual glassine trays. This was a tradition followed

* Corresponding author. 
by many entomologists in the "enlightened" Europe, like the naturalist Eugen Johann Christoph Esper (1742-1810), Johann Christian Gerning (1745-1802), and Johann Dominikus Schultze (1751-1790).

Koy was specialized on European insects. There was no evidence for his interest in exotic (non-European) species (Koy 1800). The Koy collection was transferred to the Natural History Department of the National Museum of Hungary in 1909 from the Technical University (ANONYmous 1909). Most probably the collection was purchased by the University from Frivaldszky. Unfortunately, the Koy collection was never inventoried. According to GAÁL (1941), the collection was housed in a large special cabinet, containing 52 drawers. Surprisingly, in some of the documented drawers there were trays containing exotic butterflies. Knowing that certain peculiarities, discovered in the Balkan Peninsula by Frivaldszky after the death of Koy, were present amongst the "curiosities", we assumed that these exotic butterflies originated from Frivaldszky (BÁLINT \& ABADJIEv 2006, BÁlint 2008).

During the battles in the uprising in 1956 a Soviet shell hit the building of the Department of Zoology of HNHM causing a severe fire, and beside many others, the Koy collection was heavily damaged. The cabinet itself and approximately 400 specimens of the Koy collection were completely annihilated (Boros 1957), and many of the secured trays show the grim of the heavy fire. The purpose of the present paper is inventorying the exotic butterfly specimens found in the Koy collection, parallel with this work to find out how many specimens of these species, if any, can be located in the exotic collection of Frivaldszky. Another interesting aspect is whether there is any remarkable record amongst the specimens we find.

This paper is dedicated to the 150th anniversary of Imre Frivaldszky's death.

\section{MATERIAL AND METHODS}

The glassine trays of individual specimens were documented using the Olympus Camedia C 7070 digital camera of the Lepidoptera collection of Hungarian Natural History Museum (HNHM). The specimens are listed alphabetically, according to the species-group name in the label of the tray. When there is no label, the valid species-group name is used in square brackets. When there are more trays representing the same species, the trays are numbered as 1 and 2.

The physical condition of the trays is characterised using the following terms: broken (when at least one glass plate of the tray is broken); intact (when there is no break in the tray); original (when the original dark green paper edge bound is present); repaired (when the original bounding is replaced partly or completely by modern light brown or vivid green paper); sooty (when traces of fire (smoke) can be discovered either on bounding or glassine edges). Size measurements are given 
in $\mathrm{mm}$. Similarly, the conditions of the specimens are given using the following terms: broken (wings broken, worn, one or two antennae missing); fair (wings in good condition, but one antenna missing); perfect (there is no damage). Specimens are on pin, and pinned to a cork stopper glued to the glassine bottom.

The valid scientific binomen for each species is given (with the present classification; see BÁLINT 2020). When the species is listed in Frivaldszky's insect collection inventory (unpublished manuscripts from 1864 in the HNHM: II. Lepidoptera europaea, 86 pp. and Lepidoptera Exotica in IV. Insecta exotica, $10 \mathrm{pp}$.), that is also referred under "Frivaldszky reference". The present-day distribution of the species is taken from the website managed by SAVELA (2020). Annotations are given concerning the nomenclature, distribution of the species, and the probable provenance of the specimens.

\section{RESULTS}

\section{Archippus}

(Fig. 1)

Tray - Repaired, intact, $100 \times 150 \times 23$.

Specimen condition - Broken (not glued, freely sliding in the tray).

Identity - Danaus plexippus (Linnaeus, 1758), of (Danaini, Danainae, Nymphalidae).

Frivaldszky reference - None.

Distribution - Nearctic and Neotropical regions, recent colonisations in the Palaearctic and Australasia.

Note - After the restoration procedure the original label lost its blue colour and became grey, and has been glued inside the tray. It is interesting that this remarkable species was not present in the collection of Frivaldszky.

\section{Bolina}

(Fig. 2)

Tray - Original, sooty, $73 \times 116 \times 23$.

Specimen condition - Perfect.

Identity - Hypolimnas bolina (Linnaeus, 1758), $\widehat{O}$ (Junoniini, Nymphalinae, Nymphalidae).

Frivaldszky reference - Diadema Bolina L. (no. 26, 2犬; no. 27, 1ㅇ).

Distribution - Indo-Malayan and Australasian regions, plus southern Arabia and Madagascar.

Note - We could not locate any Frivaldszky specimen. 


\section{Chrysippus [1]}

(Fig. 3)

Tray - Original, intact, $87 \times 117 \times 23$.

Specimen condition - Perfect.

Identity - Danaus chrysippus (Linnaeus, 1758) o (Danaini, Danainae, Nymphalidae).

Frivaldszky reference - None.

Distribution - Afrotropical, Indo-Malayan and Australasian regions, penetrating to the Palaearctic in the Arabian and Mediterranean regions.

Note - Frivaldszky did not list the species amongst his Lepidoptera Exotica, four specimens are inventoried in the rubric no. 202 of his Lepidoptera Europaea as "Danaus Chrysippus", from "Ins Graec". The species was first recorded in Europe by his collectors from Crete ( $c f$. FRIVALDSZKY 1845). None of these specimens could be found.

\section{Chrysippus [2]}

(Fig. 4)

Tray - Repaired, intact, $87 \times 118 \times 23$.

Specimen condition - Broken (base of wings consumed by dermestids, left antenna tip missing, right forewing apex broken).

Identity - Danaus chrysippus (Linnaeus, 1758), ô (Danaini, Danainae, Nymphalidae).

Frivaldszky refence - None.

Distribution - See above „Chrysippus [1]”.

Note - See above „Chrysippus [1]”.

\section{[Cytherea]}

(Fig. 5)

Tray - Repaired, intact, $50 \times 65 \times 20$.

Specimen condition - Broken (wings worn, left antenna missing).

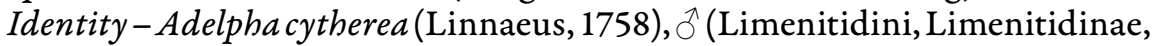
Nymphalidae).

Frivaldszky reference - None.

Distribution - Neotropical. 

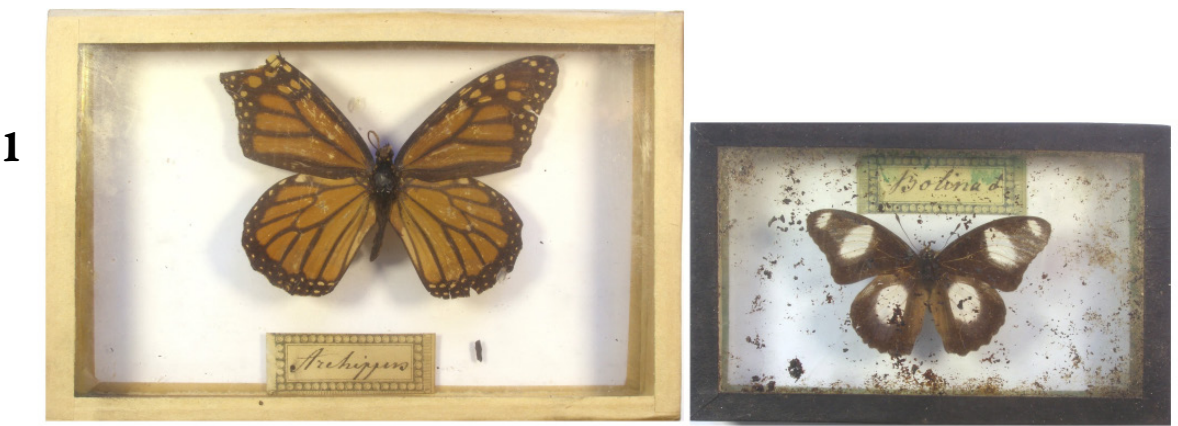

3
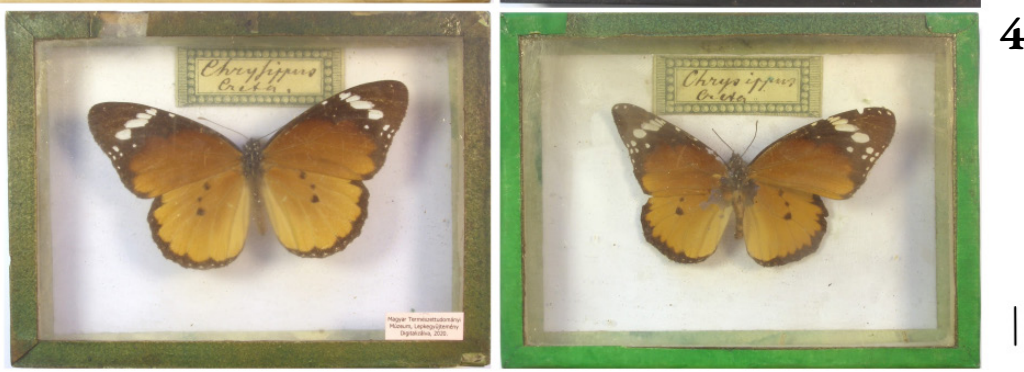

Figs 1-4. Exotic butterfly specimens of the Koy collection: $1=$ Danaus plexippus (Linnaeus, 1758), 2 = Hypolimnas bolina (Linnaeus, 1758), 3-4 = Danaus chrysippus (Linnaeus, 1758).

Scale bar $=1 \mathrm{~cm}$

[Dara]

(Fig. 6)

Tray - Intact, sooty, original, $48 \times 64 \times 20$.

Specimen condition - Fair (right wings slightly broken).

Identity - Pothantus dara (Kollar, [1844]), ㅇ (Hesperiini, Hesperiinae, Hesperiidae)

Frivaldszky reference - None.

Distribution - Indo-Malayan.

Note - The specimen was probably sent to Frivaldszky by the describer (see Discussion). 


\section{Lemonias}

(Fig. 7)

Tray - Repaired, sooty, broken, $73 \times 118 \times 22$.

Specimen condition - Perfect.

Identity - Junonia lemonias (Linnaeus, 1758), ô (Junoniini, Nymphalinae, Nymphalidae).

Frivaldszky reference - Junonia Lemonias F. (no. 83, „Ind or”, $\mathrm{n}=3$ ).

Distribution - Oriental region.

Note - We were able to find a male of the three specimens listed by Frivaldszky's Lepidoptera exotica.

\section{Menalcas [1]}

(Fig. 8)

Tray - Original, intact, $48 \times 65 \times 20$.

Specimen condition - Broken (left hindwing broken, right antenna missing).

Identity - Heliopetes arsalte (Linnaeus, 1758), $\hat{\sigma}^{\hat{T}}$ (Pyrgini, Pyrginae, Hesperiidae)

Frivaldszky reference - None.

Distribution - Neotropical region.

Note - The name Papilio menalcas Fabricius, 1775 is a junior synonym of Papilio arsalte, and a junior homonym of Papilio menalcas Poda, $1761=$ Cyanophrys amyntor (Cramer, 1775) (Lycaenidae).

\section{Menalcas [2]}

(Fig. 9)

Tray - Original, intact, $48 \times 65 \times 20$.

Specimen condition - Fair (left antenna missing).

Identity - Heliopetes arsalte (Linnaeus, 1758), + (Pyrgini, Pyrginae, Hesperiidae).

Frivaldszky reference - None.

Distribution - Neotropical region. 
5
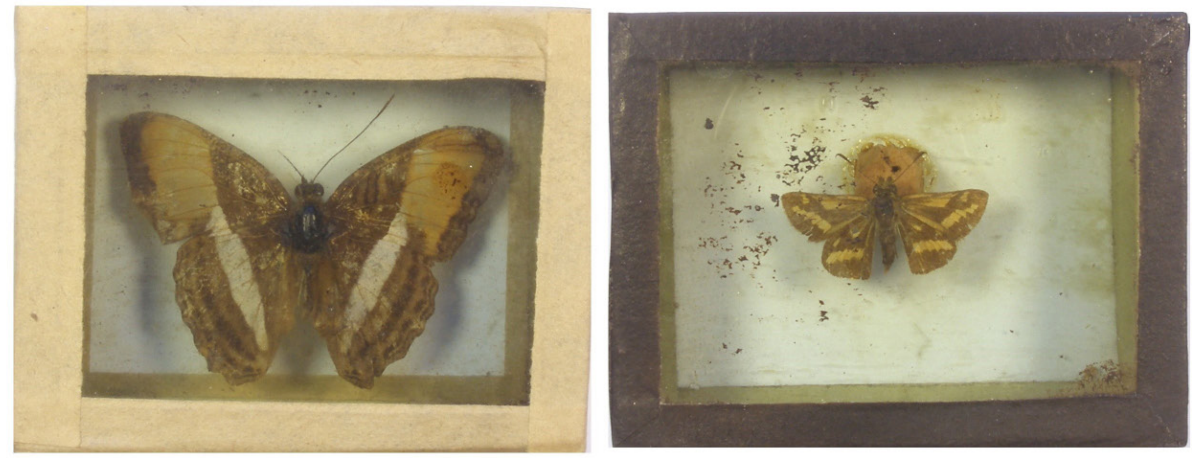

\section{7}

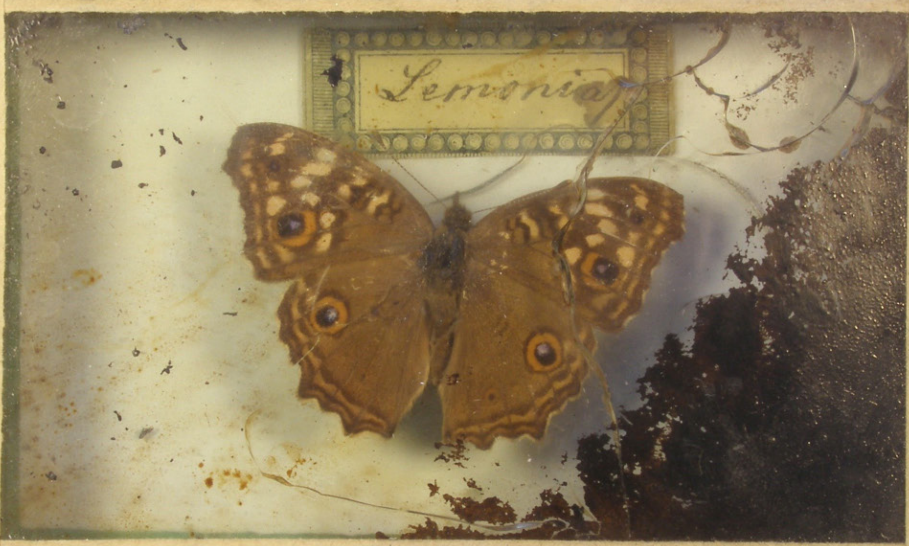

8
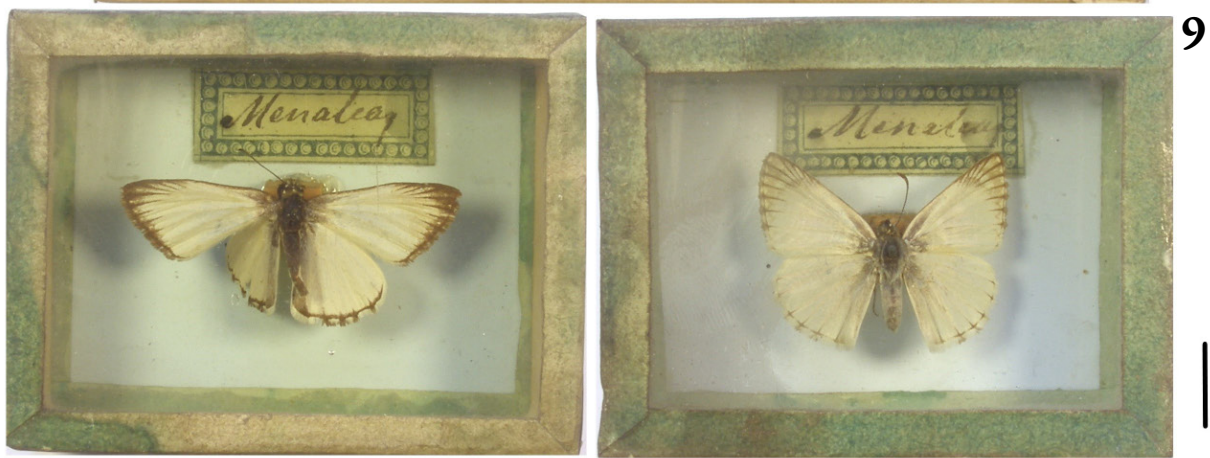

Figs 5-9. Exotic butterfly and skipper specimens of the Koy collection: $5=$ Adelpha cytherea (Linnaeus, 1758), 6 = Potanthus dara (Kollar, [1844]), 7 = Junonia lemonias (Linnaeus, 1758), $8-9=$ Heliopetes arsalte (Linnaeus, 1758). Scale bar $=1 \mathrm{~cm}$ 


\section{Mina}

(Fig. 10)

Tray - Broken, repaired, sooty, $100 \times 116 \times 22$.

Specimen condition - Perfect.

Identity - Euploea core (Cramer, [1780]), ô (Danaini, Danainae, Nymphalidae).

Frivaldszky reference - Euploea Cora (no. 31, $\mathrm{n}=2$ ).

Distribution - Australasian and Indo-Malayan regions.

Note - We were unable to find out the origin of the name "Mina". We were able to find one male specimen of $E$. core originating from the Frivaldszky collection, but it bears the original label "FRIV [//] 31". In the Frivaldszky's Lepidoptera Exotica inventory under this number the taxon "Euploea Laertes" is listed. Similar to "Mina", there is no such nominal taxon in the subfamily according to ACKERY \& WANE-WRIGHT (1984).

\section{Sara}

(Fig. 11)

Tray - Repaired, sooty, intact, $73 \times 117 \times 23$.

Specimen condition - Perfect.

Identity - Heliconius sara (Fabricius, 1793), đ̂ (Heliconiini, Heliconiinae, Nymphalidae)

Frivaldszky reference - Heliconia Sara (no. 65, "Cayen"n = 3).

Distribution - Neotropical region.

Note - We were able to find two males of the three specimens listed by Frivaldszky's Lepidoptera Exotica.

\section{Vanilia}

(Fig. 12)

Tray - Broken, repaired, sooty, $72 \times 116 \times 23$.

Specimen condition - Fair (antennae missing).

Identity - Agraulis vanillae (Linnaeus, 1758), $\widehat{~}$ (Heliconiini, Heliconiinae, Nymphalidae).

Frivaldszky reference - Heliconia Vaniliae (no. 78, n = 3); Papilio Vanilia (no. $347, \mathrm{n}=2$ ).

Distribution - Neotropical region.

Note - We were able to find only one of the two specimens listed by Frivaldszky's Lepidoptera Exotica under no. 347. 

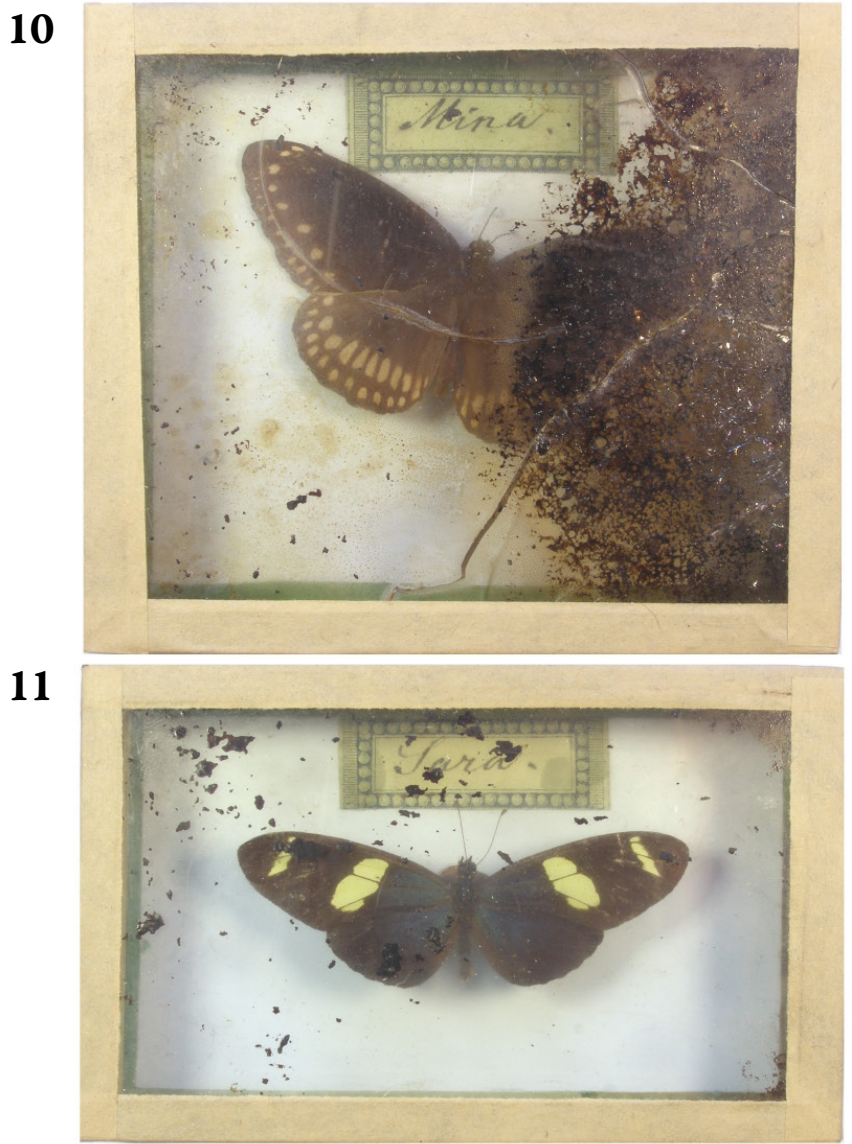

12

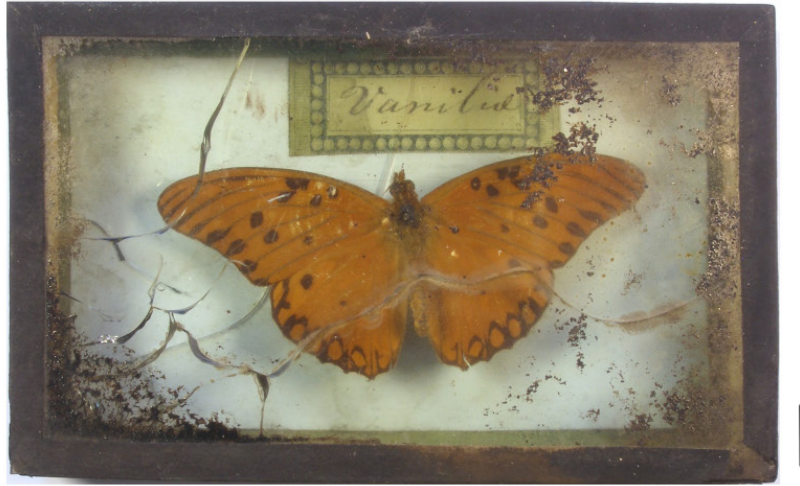

Figs 10-12. Exotic butterfly specimens of the Koy collection: $10=$ Euploea core (Cramer, [1780]), $11=$ Heliconius sara (Fabricius, 1793), $12=$ Agraulis vanillae (Linnaeus, 1758). Scale bar $=1 \mathrm{~cm}$ 


\section{DISCUSSION}

The origin of the trays

We are of the opinion that the trays of the Koy collection containing exotic Lepidoptera originate from Frivaldszky. This statement is based on the followings: (1) There are many trays in the collection which have labels inside the trays, and they never contain exotic species. The letters printed in these labels are identical with those, which were used to print the catalogue of Koy (1800). Thus, these trays most probably were created by Koy himself (Figs 13, 15). (2) There are several trays which contain species discovered by Frivaldszky subsequently to Koy's death. In these trays there are no Koy labels, but a label identical in shape and script with trays containing exotic Lepidoptera, is glued always outside to the bottom of each tray (Fig. 14). This label is a commercial one, which was widely available at the end of the 19th century. The handscript most probably originates from Frivaldszky. The label is glued in a way to display the species-group name from above. (3) Consequently it can be stated with great certainty that the trays containing exotic butterflies and skippers were created by Frivaldszky.

\section{The aim of the trays}

The inventory of Frivaldszky's Lepidoptera Exotica contains 366 rubrics and lists 588 specimens. Most of the species are common, well-known taxa. In this inventory, we could find some species which were placed also in trays. These were located in the general collection, i.e. pinned specimens in drawers (Fig. 16). We suspect that with putting the selected species in trays the intent of Frivaldszky was to show phenotypes of butterflies grossly different compared to the wellknown European fauna. So the visitor could gaze the large exotic papilionoids (Fig. 17), danaids, colourful heliconiids and nymphalids or the curious little white skipper holding the trays in hands without the fear of damaging the specimens, and with the possibility of studying the upper- and undersides of the wings at the same time. Via this method, the novelties of recent discoveries could also be shown immediately. Not only the hitherto unknown species from the Balkan, but also the discoveries of other lepidopterists, which were not so colourful but most probably they were represented in Hungary only by that very single specimen possessed by Frivaldszky (see Fig. 11). 


\section{Possible types in the collection}

We hypothesize that in the Koy collection there should be some specimens with historical interest. These could be hitherto unrecognized syntypes or specimens certainly originating from the stock of the type material, but the describer did not see the actual specimen of the Koy collection. We know that Koy sent many specimens to Esper, but the evidence that he received back the specimens is weak. For example, the blue female phenotype of Lysandra bellargus (Rottemburg, 1775), very rare in Hungary, was described as Plebejus (Ruralis) ceronus by Esper (1784) on the basis of a single female specimen collected by "in der Gegend von Pressburg von Ungarn" (Pressburg = Pozsony, now Bratislava, Slovakia) by a certain "Kummel". In the list compiled by Koy in 1800, the species was already mentioned. We presume that the identified specimen in the Koy collection as "ceronus Esp." is the holotype, sent in exchange to Koy by Esper (Fig. 15). In regard of Frivaldszky, it is obvious that he put representative specimens of his Balkan discoveries in trays (Hipparachia amalthea Frivaldszky, 1845, Lycaena anteros Freyer, 1838, L. sephirus Frivaldszky, 1835) as most probably he was proud of them. However, some specimens seem to be insignificant, were put also in trays by Frivaldszky, for example the female specimen of $P$. dara (Fig. 6), most probably because he got it directly from the describer Vincenz Kollar (1797-1860), the curator of the Imperial Natural History Cabinets in Vienna, with whom Frivaldszky was in contact.

\section{SUMMARY}

Based on pieces of evidence we demonstrated that the Koy collection of great historical importance housed in the HNHM, which was believed that it was created by Tobias Koy, actually was a mixture of specimens originating from Koy and Imre Frivaldszky. This collection was most probably kept as a cabinet of curiosity, not only containing European, but also exotic species and specimens of new discoveries. Although certainly there were more (see Fig. 17), 12 individual trays were located with exotic Lepidoptera specimens, underlying that the purpose of the collection was to display the diversity of Lepidoptera in a worldwide aspect. Koy, as well as Frivaldszky was in tight contact with contemporary prominent scientists. Consequently, amongst the specimens kept in the trays there are hitherto unrecognised types or specimens originating from the lot of the type series. The collection was heavily damaged in 1956 and trays in large numbers have been destroyed. Amongst the remaining 935 individual trays, many of them had to be repaired, but in spite of this many displays the remnants of the great fire annihilated important collections of the HNHM. 


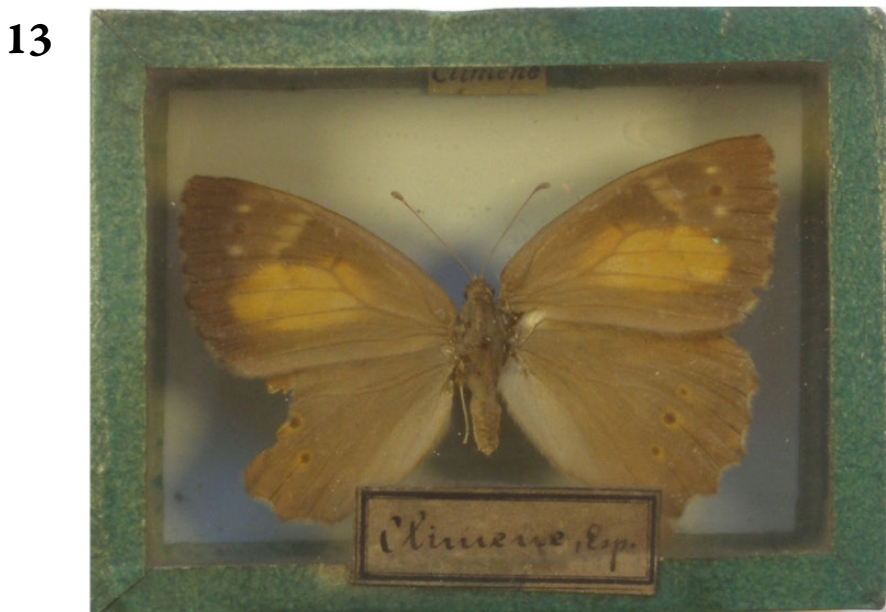

14

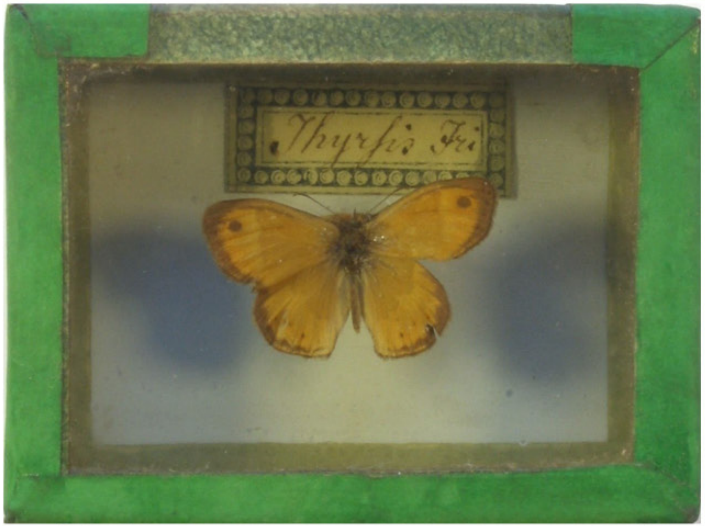

15

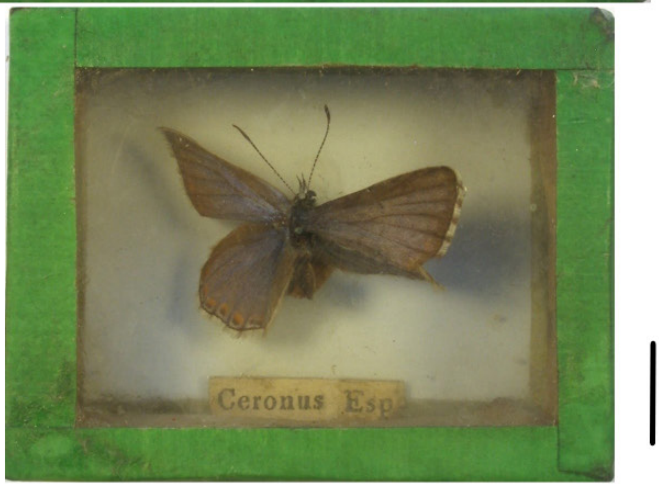

Figs 13-15. European butterfly specimens of the Koy collection: $13=$ Espararge climene Esper (1783), 14 = Coenonympha thyrsis (Freyer, 1845), 15 = Lysandra bellargus (Rottemburg, 1775). Scale bar $=1 \mathrm{~cm}$ 


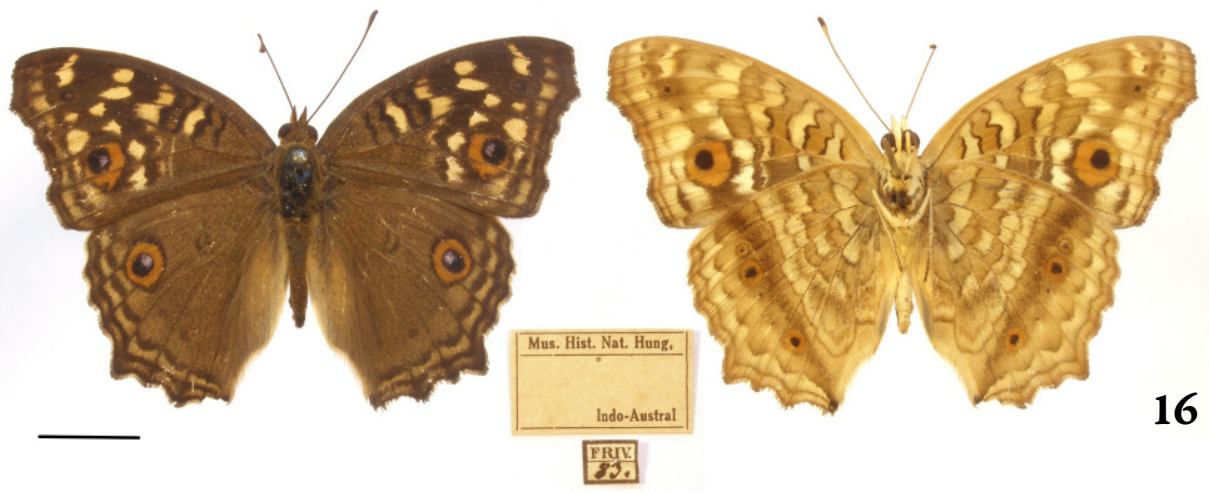

Fig. 16. Pinned specimen of exotic butterfly Junonia lemonias (Linnaeus, 1758) and its labels from the Frivaldszky collection. Scale bar $=1 \mathrm{~cm}$ (all photos by Gergely Katona)

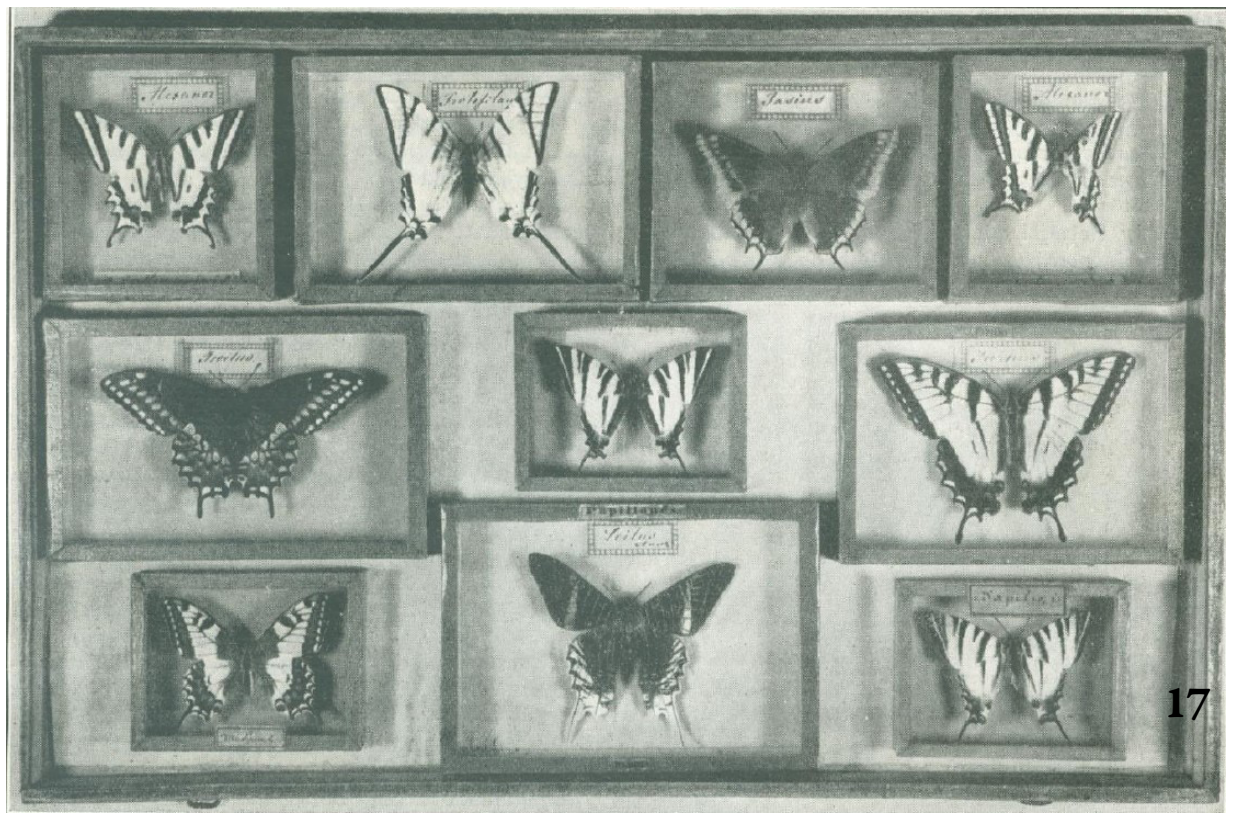

Fig. 17. One of the drawers of the Koy collection containing European and exotic butterfly and moth specimens. Only the tray "Jasius", Charaxes jasius (Linnaeus, 1767), can be found today, all the others have been destroyed (reproduced from GAÁL 1941) 


\section{REFERENCES}

Ackery R. P. \& VAne-Wright R. I. 1984: Milkweed Butterflies. Their cladistics and biology. Being an account of the natural history of the Danaidae, a subfamily of the Lepidoptera, Nymphalidae. - British Museum (Natural History), London, 425 pp.

ANonymous 1909: A Magyar Nemzeti Múzeum rovargyűjteményeinek gyarapodása 1909-ben. [Accessions of the entomological collections of the National Museum of Hungary in 1909.] - Rovartani Lapok 17: 120.

Bálint Zs. 2002: Koy Tóbiás. - In: Bodó S. \& VigA Gy. (eds): Múzeumi Arcképcsarnok. [A Collection of Museologists' Portaits] - Pulszky Társaság, Tarsoly Kiadó, Budapest, p. 509.

BÁLINT Zs. 2008: Lepidoptera collections of historical importance in the Hungarian Natural History Museum. - Annales historico-naturales Musei nationalis hungarici 100: 17-35.

BÁLIN Ts. 2020: Szöglencek, pazarkák, lángszinérek. Egzotikuspillangóalakú lepkék gyüjteménye. [Anglewings, Metalmarks, Coppers. A collection of exotic papilionoid butterflies.] - Published by the author, Budapest, $71 \mathrm{pp}, 100$ pls.

BÁlint Zs. \& ABAdjIEv S. 2006: An annotated list of Imre Frivaldszky's publications and the species-group and infraspecies names proposed by him for plants and animals (Regnum Plantare and Animale). - Annales historico-naturales Musei nationalis hungarici 98: 185-280.

Boros I. 1957: The tragedy of the Hungarian Natural History Museum. - Annales historiconaturales Musei nationalis hungarici 49: 491-505.

FRIVALDSZKY I. 1845: Rövid áttekintése egy természetrajzi utazásnak, az európai Törökbirodalomban, egyszersmind néhány a közben újdonnat fölfedezett állatnak leírása. [Brief overview of a natural history journey taken in the European part of the Ottoman Empire, supplemented with the description of some newly discovered animals.] - $A$ Királyi Magyar Természettudományi Társulat évkönyvei 1: 163-187.

GA ÁL I. 1941: Százévesnél régibb lepkepéldányok a Nemzeti Múzeumban. [Lepidoptera specimens older than a hundred years housed in the National Museum.]- A Természet 37(5): 64-66.

KoY T. 1800: Alphabetisches Verzeichniss meiner Insekten Sammlung. [Alphabetical list of my insect collection.] - Gedruckt mit Königl. Universitäts-Schriften, Ofen, 64 pp.

SAVELA M. 2020: Lepidoptera and some other life forms. - Online: https://www.nic.funet.fi/pub/sci/bio/life/intro.html [Accessed 1 October 2020.] 